Neurologijos seminarai 2020; 24(86): 299-308

DOI: $10.29014 / \mathrm{ns} .2020 .38$

\title{
Šokio terapija neurologijoje
}

\section{M. Šeduikiené* V. Matonis**}

*Lietuvos sveikatos mokslu universitetas, Medicinos fakultetas

**Nepriklausomas tyrejas
Santrauka. Naujausių šokio terapijos publikacijų analizė parodè, kad didesnė tyrimų pusė yra skirta nervų ligoms gydyti ar simptomams lengvinti, pasitelkiant šokị. Pastebimas daugelio nervų ligų ir sutrikimų (Parkinsono ligos, cerebrinio paralyžiaus, Alzheimerio ligos ir kt.) spartus tyrimų gausėjimas, gydymui, reabilitacijai ar profilaktikai taikant ịvairius šokius: tango, salsą, sambo, rumbą, lindihopą, merengue, baletą ir kt. Populiarumu ir pasiekimais labiausiai išsiskiria Parkinsono ligos simptomų lengvinimo tango šokiu tyrimai ir praktiniai užsièmimai. Nervų ligų gydymo šokiu tyrimų plètotẻ rodo šokių poveikio efektyvumą ir išaugusị jų poreikị. Apžvelgiami darbai suskirstyti ị šešis skyrius: 1) gausėjantys šokio gydomojo vaidmens tyrimai ir populiarẻjanti šokio gydomoji praktika, 2) šokis - aktualëjanti motorinio, pažintinio, emocinio, vizualinio ir socialinio aktyvinimo priemonė, 3) Parkinsono ligos simptomų lengvinimas šokiu, 4) šokio terapijos neurologijoje galimybių plètra ir ribos, 5) šokio estetinio patyrimo poveikis nervų sistemai ir 6) šokio poreikio augimas sveikatingumo programose. Keista, kad ši greitai iškerojusi tyrimų ir gydymo sritis dar niekaip neįvardinta. Atsižvelgiant ị šokio gydomosios veiklos apimtị ir specifiką, neurologinių sutrikimų gydymo šokio intervencija specializaciją tikslinga būtų pavadinti šokio terapija neurologijoje (S̆TN). Vis didesnių šokio terapinių galių atskleidimas, įtraukiant ir estetinius ypatumus, bei šokio ịsitvirtinimas ịvairiose neurologinèse programose rodo ŠTN raidos perspektyvą.

Raktažodžiai: šokio terapija, neuroestetika, neurologiniai sutrikimai, Parkinsono liga, šokio intervencija.

\section{IVADAS}

Kartu su šokio neuromokslo raida pasaulyje gyvai rutuliojasi nauja neurologijos specializacija - šokio terapija neurologijoje (ŠTN). Jos galimybes tapti svarbiu neurologinių simptomų lengvinimo instrumentu sparčiai plečia atradimai, įrodantys šokio galimybes teigiamai veikti ịvairius neurologinius sutrikimus. Nustatyta, kad šokis kartu su skambančia muzika daro dvigubą poveikị smegenims: muzika stimuliuoja smegenų atlygio sistemą, o šokis aktyvina sensorines ir motorines grandines. Pozitronų emisijos tomografas (PET) gana aiškiai parodo smegenų dalis, kurios dalyvauja šokant. Tai:

- motorinè žievé, susijusi su valingų veiksmų planavimu ir kontrole;

\author{
Adresas: \\ Milda Šeduikiene \\ Lietuvos sveikatos mokslu universitetas \\ A. Mickevičiaus g. 9, LT 44307 Kaunas \\ El.paštas jasutytem@gmail.com
}

- kūno somatosensorinė žievè, atsakinga už motorikos kontrolę ir palaikanti akių bei rankų koordinaciją;

- pamato branduoliai, kurie kartu su kitomis smegenų dalimis sklandžiai koordinuoja judesius;

- smegenėlès, kurios integruoja iš galvos ir nugaros smegenų gaunamą informaciją ir padeda suplanuoti bei koordinuoti sudėtingų judesių veikimą.

Šokio galia aktyvinti įvairias smegenų dalis paskatino neurologus labiau ịsigilinti ị įvairių šokių terapines galimybes. Pavyzdžiui, jau žinoma, kad šokis pagal metrinio ritmo muziką yra susijęs su pamato branduoliais, o šokis pagal nemetrinio ritmo muziką, kurioje nėra taktų [1], - su tarpinių smegenų gumburu ir smegenèlèmis. Būtent dèl specifinių poveikio ypatumų ypač išpopuliarejjo šokio (ypač tango) naudojimas kaip priemonès, lengvinančios Parkinsono ligos (PL) eigą. Taip pat efektyviai šokio intervencija veikia ligonius, sergančius demencija, gydant valgymo sutrikimus, lengvinant autizmo simptomus, gerinant galūnių judesius ligoniams, sergantiems cerebriniu paralyžiumi, ir esant daugeliui kitų sutrikimų. Atsiranda darbai, įrodantys šokio vizualinio ir estetinio suvokimo poveiki smegenims.

(C) Neurologijos seminarai, 2020. Open Access. This article is distributed under the terms of the Creative Commons Attribution 4.0 International License CC-BY 4.0 (http://creativecommons.org/licenses/by/4.0/), which permits unrestricted use, distribution, and reproduction in any medium, provided you give appropriate credit to the original author(s) and the source, provide a link to the Creative Commons license, and indicate if changes were made. 
Iš viso suskaičiuojama per 600 neurologinių sutrikimų [2]. Šokių visame pasaulyje suskaičiuojama dar daugiau, bendrame sąraše jų pateikiama apie 1000 [3]. Nors šokio paklausa sparčiai auga ir šokis vis labiau įsitvirtina ne tik bendro sveikatinimo, bet ir ívairiose neurologinėse programose, dar lieka daug neišnaudotų galimybių. Toliau pateikiamas šokio, kaip lengvinančio nervų ligų simptomus instrumento, detalesnis apibūdinimas.

\section{GAUSĖJANTYS ŠOKIO GYDOMOJO VAIDMENS TYRIMAI IR POPULIARĖJANTI GYDOMOJI PRAKTIKA}

Dešimtis tūkstantmečiu visose kultūrose ir visose socialinėse grupėse šokis (kartu su muzika) buvo ypatinga emocijų raiškos ir komunikavimo priemonè, tad žmogaus evoliucijoje jis suvaidino išimtinai reikšmingą vaidmenị. Šokis dažnai buvo pasitelkiamas esant pakitusioms sąmonės būsenoms, o šamanizme sinergistinis poveikis buvo išgaunamas naudojant šokio, muzikos ir narkotinių medžiagu mišinị. Kultūriniame gyvenime šokis evoliucionavo, įsikūnydamas daugelyje žanrų ir stilių. Būta istorijoje ir neigiamų požiūrių ị šokị. Antai senovés romėnų laikotarpiu šokantieji dažnai būdavo tiesiog pajuokiami. Pasak Cicerono (106-43 pr. Kr.), žmogus, būdamas blaivus, jeigu tik nėra pamišęs, nešokinėja.

Pirmą kartą šokị, kaip efektyvią psichoterapijos formą, 1916 m. įvertino Carl Gustav Jung (1875-1961), šią meno šaką pavadinęs aktyvios vaizduotès procesu. Ir tik $\mathrm{XX}$ a. antroje pusejje šokio terapija, kaip profesija, imta taikyti praktiškai. Šios veiklos pradininke tapo JAV šokèja Marian Chase (1896-1970). Ji 1942 m. pradèjo dirbti Vašingtono psichiatrijos ligoninejje, kurios palatos ėmė pildytis asmenimis, psichologiškai nukentėjusiais per Antrajị pasaulinį karą. Jos ten pasiūlytas „bendravimo šokis" tapo šokio ir judesio terapijos pirmtaku. Šokio terapiją, kaip profesiją, jau XX a. antroje pusejje ịtvirtino modernaus šokio šokeja Mary Starks Whitehouse (1911-1979). İkvèpta C. G. Jung idejjų, ji ị šoki pažiūrèjo kaip ị kūno ir dvasios neatskiriamą vienumą, judesiais skatindama asmens savityrą, budindama protines galias ir didindama savivertę.

İdomu, kad publikacijų, kurios tyrinejja šokio gydomąjị vaidmenị nervų ligomis sergantiems žmonėms, skaičius pastaraisiais dešimtmečiais išaugo jau ne dešimtimis, o šimtais kartų. Vakarų Šveicarijos taikomujų mokslų ir menų universiteto (Ženeva) profesorè Anne-Violette Bruyneel, naudodamasi PubMed/Medicine ir Kinedoc duomenų bazèmis, pagal reikšminį žodị "dance“ surinko net 2380 straipsnių anglų ir prancūzų kalbomis [4]. Pirmiausia krinta ị akis, kad šio pobūdžio publikacijų skaičius nepaprastai staigiai augo - nuo kelių per metus XX a. viduryje iki beveik $6002018 \mathrm{~m}$. Jos parengtoje diagramoje išvardijama net 16 šokio intervencija gydomų lẻtinių ligų ir simptomų. Suklasifikuotos pagal tyrimų kiekį atskirai patologijai, publikacijos mažèjančia tvarka išsidèstė taip: PL, vè- žys, cerebrinis paralyžius, širdies ligos, reumatoidinis artritas, diabetas, nutukimas, fibromialgija, šizofrenija, senyvo amžiaus žmonių griuvimai, apatinès nugaros dalies skausmas, Alzheimerio liga, nugaros smegenų sutrikimai (spinal cord), išsėtinė sklerozė, smegenų infarktas (stroke) ir protinis atsilikimas. Taigi, kaip rodo ši diagrama, daugiausia publikacijų, kuriose aprašomi gydymo šokiu tyrimai, yra skirta PL gydyti. O skirstant pagal patologijas, daugiau nei pusė straipsnių apie šokio vaidmenị buvo skirta neurologinèms ligoms gydyti. Vadinasi, galima tvirtinti, kad ŠTN tyrimai kiekybiškai ir kokybiškai pasieke gana aukštą lygì.

A. V. Bruyneel skaičiavimais, skirstant pagal žemynus, daugiausia publikuotų tyrimų apie šokio gydomają galią paskelbta Šiaurès Amerikoje (47,05 \%). Antra vieta teko Europai (29,41 \%), trečia - Azijai (11,76 \%), ketvirta - Pietu Amerikai (7,84 \%), o Afrika su Australija ir Okeanija atsidūrè penktoje vietoje (po 1,97 \%). Pagal žanrus, populiariausi gydymui naudojami yra pramoginiai šokiai $(37,25 \%)$, mažiausio populiarumo susilaukè baleto šokis $(5,88 \%)$.

Sveikintina, kad Vilniaus universiteto Medicinos fakultete jau rengiami judesio ir šokio terapijos magistrai, kurie, kaip skelbiama studijų programoje, „galès dirbti ligoninėse, psichikos sveikatos centruose, reabilitacijos ir sanatorinio gydymo bei kitose asmens sveikatos priežiūros įstaigose, globos namuose, dienos centruose, krizių centruose bei kitose socialinių paslaugų ịstaigose; specialaus ugdymo įstaigose; NVO (nevyriausybinèse organizacijose - autoriu past.) ir privačiuose sektoriuose arba tęsti studijas doktorantūroje užsienyje arba Lietuvoje“ [5].

Šokio gydomoji praktika sparčiai populiarèja visame pasaulyje, aktyvina veiklą daugelyje šalių įsikūrusios šokio terapijos asociacijos. Kartu, kaip rodo apžvelgiami tyrimai, sparčiai ėmė augti ŠTN poreikis.

\section{ŠOKIS - AKTUALĖJANTI MOTORINIO, PAŽINTINIO, EMOCINIO, VIZUALINIO IR SOCIALINIO AKTYVINIMO TERAPINE் PRIEMONE}

Pastaraisiais dešimtmečiais, klinikiniams eksperimentams pasitelkus atitinkamą šokio intervenciją, buvo atrasta naujų gydymo metodų, kurie gali palengvinti neurologinius sutrikimus. Kaip pavyzdi galima paminèti Londono imperatoriškojo koledžo ir Čaring Kroso ligoninès neurologu Diego Kaski ir Adolfo M. Bronstein atliktą eksperimentą, kuriuo jie pabandè palengvinti pacientų eisenos ir pusiausvyros sutrikimus [6]. Kadangi šie sutrikimai yra sunkiai gydomi, jie vieni pirmujų pabandė juos paveikti, naudodami anodinę transkranijinę tiesioginès srovès stimuliaciją (angl. transcranial direct current stimulation, tDCS). Eksperimentuojant vienu metu buvo stimuliuojami abu smegenų pusrutuliai. Naujas tDCS metodas buvo derinamas su fizine terapija ir taikomas pacientams, turintiems motorikos ir pusiausvyros sutrikimų bei sergantiems PL. Šią gy- 
dymo naujovę neurologai nutarè suderinti su šokiu. Išsiaiškinę, kad, taikant judesių ir šokių terapiją, pavyksta pagerinti pacientų eiseną ir pusiausvyrą, jie ypač susidomėjo argentinietiško tango galimybėmis. Kadangi jų atrastas tDCS metodas taip pat gerina sergančiųjų PL eiseną ir pusiausvyrą, ji nutare išbandyti su pacientais šokant tango. Pagal užduočių vertinimo skalę buvo fiksuojami eisenos ir pusiausvyros parametrai, kaip antai, gebėjimas atsistoti nuo kẻdès, pusiausvyros išlaikymas stovint, žingsnių simetrija ir pan. Paaiškèjo, kad pacientų, šokusių tango, liemens išsitiesinimo greitis buvo daug didesnis, kai buvo naudojama tDCS. Teigiami buvo ir subjektyvūs tobulesnio šokio vertinimai. Šokio partneriai vertino, kad pacientai atliko daug didesnį žingsnių kiekį, taip pat pagerèjo jų eisena.

Tyrimą, susijusį su salsos poveikiu kūno pusiausvyrai, atliko Indonezijos medikai. Kadangi tarp daugiau kaip $20 \mathrm{mln}$. (8,03\%) pagyvenusių Indonezijos gyventojų vieni dažniausių fizinių sutrikimų yra kūno pusiausvyros sutrikimai ir su jais susijusi griuvimo rizika, tyrejjai susikoncentravo ties šia problema. Išsiaiškinus, kad salsos šokio judesiai gerina lankstumą, judrumą ir pusiausvyrą, buvo nutarta smulkiau patyrinèti šio šokio efektyvumą. Rezultatai patvirtino hipotezę: lyginant su kontroline grupe, šokusių pagyvenusių žmonių kūno pusiausvyra po 10-20 reguliariai vykdomų intervencijų reikšmingai pagerejjo [7].

Septyni Salonikų Aristotelio universiteto (Graikija) mokslininkai užsibrèžè tikslą ištirti pramoginių šokių poveikị pagyvenusiems asmenims, kuriems dèl susilpnèjusios atminties buvo sutrikusios kognityvinès funkcijos. I dvi grupes suskirsčius 129 pacientus, eksperimentinè grupè (66 pacientai) 10 mėnesių (du kartus per savaitę, po vieną valandą) sistemingai vykdè numatytą šokių programą. Palyginus abiejų grupių neuropsichologinius testus (reakcijos laikas, vizualiniai erdviniai igūdžiai, dèmesys, nuotaika, kalbejjimo laisvumas ir kt.), atliktus prieš šokant ir po 10 mėnesių šokių, paaiškèjo didelẻ šokio intervencijos, kaip nefarmakologinès priemonès, nauda. Šokusiųų kognityvinès funkcijos pagerèjo, daugumą užduočių jie atliko geriau negu kontrolinès grupès pacientai [8].

Dvylikos Masaryko universiteto (Čekija) mokslininkų grupė atliko eksperimentinị tyrimą, palygindami šokio intervencijos poveiki sveikų pagyvenusių žmonių kognityvinèms funkcijoms ir pagyvenusiems žmonèms su suprastejjusiomis kognityvinėmis funkcijomis. Tyrëjus domino, ar šokio judesių poveikis pagyvenusių žmonių kognityvinėms funkcijoms priklauso nuo hipokampo atrofijos. Visus 99 tiriamuosius jie suskirstė ị dvi grupes. Abiejose grupėse buvo ir sveikų, ir su suprastejusiomis kognityvinèmis funkcijomis senjorų. Vienos grupès tiriamiesiems (49 asmenys) šešis mènesius buvo taikoma 60 pamokų šokio intervencija. Lyginant su kontroline grupe, jie daug laisviau atliko figūrines užduotis [9].

Šokiu grindžiamose gydymo programose ir toliau ieškoma, kaip šokio intervencija kuo sėkmingiau paveikti neurologinius sutrikimus. Siekiant pakelti nuotaiką, sumažinti stresą ir nerimą, nervinis aktyvumas stimuliuojamas įvairinant pratimus, parenkant atitinkamą muziką, netgi pasitelkiant specifinius bendravimo šokant ypatumus, pavyzdžiui, partnerystę [10].

Bene didžiausi ŠTN pasiekimai kol kas matomi lengvinant PL simptomus.

\section{PARKINSONO LIGOS SIMPTOMU LENGVINIMAS ŠOKIU}

Floridos universiteto (JAV) neurologai Melissa J. Armstrong ir Michael S. Okun naujausiame tyrime atkreipè dèmesị, kad PL plinta sparčiau už kitas neurologines ligas ir užima antrą vietą po Alzheimerio ligos. Jų žiniomis, pasaulyje ja serga daugiau nei $6 \mathrm{mln}$. Vyrai šia liga suserga dažniau nei moterys $(1,4: 1,0)$. PL sukelia dopaminerginių neuronų žūtis smegenų juodojoje medžiagoje, kuri yra susijusi su judejimu, taigi ir šokiu [11].

Tad kuo gali pagelbėti šokis, pasirodžius PL simptomams? Žinoma, pačių neurodegeneracinių procesų šokis nepašalins. Tačiau jis gali palengvinti ligos simptomus. Kaip tik ši šokio funkcija ir sudomino choreografus. Antai net pasaulyje išgarsėjęs šokejjo ir choreografo Marc Morris 2001 m. Brukline (Niujorkas) įkurtas šokių centras ị darbotvarkę įtraukė ir žmonėms su negalia, įskaitant sergančiuosius PL, skirtą šokio programą.

Brazilijos mokslininkai pabandė išaiškinti PL gydymo galimybes, panaudojant braziliškos sambos intervenciją [12]. Jų tyrimo tikslas buvo nustatyti alternatyvų nefarmakologinị būdą, kuris pagerintų judumą, pusiausvyrą, eiseną, laikyseną ir apskritai sergančiujuc gyvenimo kokybę. Po 12 savaičių trukusių sambos užsièmimų, kai buvo šokama du kartus per savaitę, tiek pirminiai motoriniai, tiek antriniai nemotoriniai dalyvių simptomai pastebimai palengvèjo.

Terapiniais tikslais veikia šokio grupès ir Lietuvoje, rengiami net sergančiųjų šokio festivaliai. Vilniaus mokytojų namai kasmet kviečia žmones, sergančius Parkinsono liga, bei jų partnerius mokytis argentinietiško tango pagal specialiai pritaikytą programą [13]. Lietuvos Parkinsono ligos draugija taip pat inicijuoja šokių, ypač tango, mokymąsi. Ieškoma ir naujų šokio terapijos galimybių. Pavyzdžiui, aiškinamasi, kiek sergantiems PL gali pagelbèti afroamerikietiškas lindihopas, kuris, manoma, dèl didelių saviraiškos galimybių gali gerokai sumažinti kai kuriuos šios ligos simptomus [14].

Platų PL sergančių šokejjų tyrimą neurologiniu lygiu atliko Osakos ir Hirošimos medicinos įstaigų (Japonija) darbuotojai [15]. Jie ištyrė 46 vidutinio sunkumo PL sergančius pacientus, kurie dalyvavo ịvairių Japonijos bendruomenių šokių būreliuose. Tyrimas truko 6 savaites, grupių užsièmimai vykdavo po $60 \mathrm{~min}$. per savaitę. Tyrimo rezultatai parode, kad, lyginant su kontroline grupe, šokis padarè teigiamą poveiki tiriamujuc eisenai, pusiausvyrai, pagerino kognityvines funkcijas (kaktinès skilties veiklą), sumažino apatijos ir depresijos simptomus, teigiamai paveikė protinius ir bendruosius ligos simptomus. Šokis buvo îvertintas kaip efektyvus metodas reabilituojant PL sergančius pacientus. 
Rečiau taikomą šokio metodą nutarè nuodugniau ištirti Rohamptono ir Portsmuto universitetų (Jungtinė Karalystè) dėstytojai. Jiems parūpo išbandyti baleto galimybes mažinti PL simptomus. Pradžioje jie ištyrè, kiek galima baleto priemonėmis pagerinti PL sergančiujuc eiseną ir pusiausvyrą. Deja, išanalizuoti 19 šokejjų tyrimo rezultatai, juos palyginus su kontroline grupe, vis dèlto nebuvo reikšmingi [16]. Tada britų medikai pabandè ištirti kitus sutrikimus, t. y. stebėti, ar, šokant baletą, gali pagerèti PL sergančiųų liemens koordinacija ir padidèti judesių amplitudè. Po metus kas savaitę vykusių baleto klasės užsièmimų ir vèl paaiškèjo, kad nei liemens koordinacija, nei judesių amplitudė žymiau nepakito. Pastebėta tik, kad PL sergantys šokejjai po užsièmimų ėmė laisviau vaikščioti ir pagerèjo jų bendra koordinacija. Nors patys tyrejjai ir vėl pripažịsta, kad šiems teigiamiems pakitimams ko gero galejjo turèti įtakos ne tik šokis, bet ir kiti veiksniai, t. y. baleto mokytojų nuolatinės žodinės replikos ir, žinoma, šokio metu skambanti muzika. Tad jie nutare išbandyti dar vieną hipotezę. Ši kartą jie viliasi, kad žymesnic poveikį PL simptomams vis tik turètų padaryti dažniau nei kartą per savaitę vykstantys baleto užsièmimai [17].

Šokio vaidmens galimybès, lengvinant PL simptomus, tiriamos gana aktyviai. Nustatytas psichoterapinis šokio vaidmuo gydant šią ligą, pastebėtos šokio galimybès gerinti viso kūno koordinaciją, motorikos simptomus, kelti gyvenimo kokybę, netgi išsiaiškinti šokio klasės dalyvių poreikius [18-21]. Galima būtų paminėti dar daugybę studijų, kuriose aprašomas teigiamas šokio poveikis įvairiems PL simptomams arba teikiamos rekomendacijos savigydai namų sąlygomis. Tačiau daugelis rezultatų vieni nuo kitų nedaug skiriasi. Labiausiai iš visų šios srities tyrimų ne tik gausumu, bet ir pasiekimais išsiskiria PL simptomų mažinimo tango šokiu tyrimai.

Tango per pastaruosius kone pusantro šimto metų kultūriniame gyvenime užèmé svarią vietą. Pelnytai $2009 \mathrm{~m}$. UNESCO ịtraukè ši šokị į nematerialiojo kultūros paveldo sąrašą. Per tango istoriją skirtingais laikotarpiais įvairiuose regionuose susiformavo keliolika jo stilių. Tango terapinėmis galiomis susidomėję Viteno Herdekès universiteto (Vokietija) Sveikatos fakulteto dèstytojai dar 2015 m. atliko šiai temai skirtų darbų sisteminę apžvalgą ir metaanalizę, kuri atskleidè daug ivvairių ypatumų [22]. Tyrimo rezultatai parodė ypač efektyvų tango poveikị ịveikiant motorikos, pusiausvyros ir eisenos sunkumus. Tiesa, eiseną matuojant $6 \mathrm{~min}$. ejjimo testu, rezultatas nebuvo statistiškai reikšmingas. Tačiau studijų sisteminė apžvalga atskleidė, kad tango pozityviai veikia nuovargị, aktyvina socialinị dalyvavimą, gerina sergančiųjų gyvenimo kokybę. Tyrẻjų manymu, ateityje vis tik reikètų didinti tyrimo dalyvių skaičių. Taip pat daugiau dėmesio reikètų skirti atskiriems asmenims ir nevengti longitudinių tyrimų, kurie geriau atskleistų tango poveiki tiek tarpasmeniniams santykiams, tiek individualiai gyvensenai.

İsitikinama, kad būtent argentinietiškas tango yra tinkamiausias PL simptomams mažinti. Mat jis iš visų šokių geriausiai atitinka natūralią judesių amplitudę. Šị tango stilių tyrimams pasirinko ir Cheju Halla pagrindinès ligoni- nės, kuri įrengta prie Pietų Korèjos esančioje Čedžu saloje, gydytojai Youngsoon Koh, Geunwoong Noh ir kt. Tyrimai buvo vykdomi labai intensyviai. Buvo ickurta ir Korejos tango terapijos asociacija, kuri ne tik kuruoja PL gydymą, bet ir rūpinasi kitų tango gydomụjų galimybių taikymu, pavyzdžiui, pagyvenusių žmonių sveikatai stiprinti, osteoporozès, moterų šlapimo nelaikymo atvejams, nutukimui, diabetui ir kitiems sutrikimams. Ypač pagirtina, kad Korèjos tango terapijos asociacija nuo 2019 m. pradejo leisti žurnalą Journal of Tango, kuriame spausdinami tango terapijos tyrimams skirti straipsniai.

Cheju Halla pagrindinės ligoninės gydytojai, atsižvelgę ị PL gydymo tyrimų rezultatus, gautus ligi tol, nutarè išsiaiškinti, kaip, sistemingai taikant atitinkamus tango elementus pagal paciento klinikinę būklę ir ligos sunkumą, būtų galima padidinti sergančiụjų gydymo efektyvumą [23-27]. Terapiniais tikslais suklasifikavę pagrindinius tango elementus ir susisteminę tango elementų terminologiją, Korejjos mokslininkai pirmą kartą funkcionaliai ir anatomiškai išanalizavo pacientų laikyseną, stovėseną, tango eiseną ir tango ocho (ocho - tai viena iš septynių ankstyvojo argentinietiško tango figūrų, kai žingsniais formuojama aštuoniukè). Tyrime dalyvavo PL sergantys pacientai. Judamų tango elementų terapija truko $10 \mathrm{val}$. ir buvo vykdoma 2 savaites. Tyrejai teigia, kad tango privalumas, gydant ne tik PL, bet ir kitas neurologines ligas, ypač vyresnio amžiaus pacientų, yra tas, kad šis šokis pakankamai saugus, negreitas ir turi panašių į specialius pratimus efektų. Be to, šokant tango, dar prisideda ir muzikos terapija, todèl reikètų atkreipti dėmesị ir į muzikos nuotaiką. Pagaliau tango terapija dar yra ir fizinè terapija, nes tango judesiai susiję su daugelio kūno raumenų aktyvinimu. O sergančiujų PL opiausia medicininė problema kaip tik ir yra jų neuroraumeninè disfunkcija. Svarbu, kad šokio greitis būtų pritaikomas prie paciento klinikinès būklès, o jai gerejjant, galima parinkti ir greitesnio tempo muziką. Taigi tango terapija išsiskiria tuo, kad daro ir fizini, ir psichologinị, ir socialinị poveikị bei gali būti naudojama gydant ne vien PL, bet ir daugelį kitų ligų.

Neurologai taip pat atkreipè dèmesị ị gydomajị partnerystès vaidmenị šokant tango. Vašingtono universiteto Medicinos mokyklos mokslininkai specialiai èmėsi tirti partnerio vaidmeni šokiu gydant PL sergančius ligonius. Išplèstinio tyrimo analizė parodè, kad sergantiems PL šokio partneris pirmiausia labai praverčia, kai pajuntamas pusiausvyros sutrikimas, nes sergantysis tokiais momentais gali juo pasikliauti. Pagal Bergo pusiausvyros skalę patikrinus ejjimo greitị ir ritmiškumą, tiek su partneriu, tiek be partnerio šokusiujų tiriamų grupių narių judejjimo kokybẻ patobulëjo maždaug vienodai. Tačiau sergančiųjų PL šokio su partneriu privalumas buvo tas, kad jie jautė didesnị pasitenkinimą šokiu ir norėjo, kad šokiai tęstųsi [28].

Nors tango šokis užima svarbią vietą gydant PL, o tango daromas poveikis atsiskleidžia įvairiais aspektais [29-31], vis daugiau vietos, gydant daugeli sutrikimų, plačiame neurologinių susirgimų kontekste skiriama ir kitiems šokiams. 


\section{ŠOKIO TERAPIJOS NEUROLOGIJOJE GALIMYBIU PLÉTRA IR RIBOS}

Grupė Kanados mokslininkų atliko sisteminę analizę tyrimų, kurie, išskyrus PL, taip pat susiję su judesių koordinacijos, pusiausvyros ir eisenos sutrikimų lengvinimu [32]. Neurologiniai tyrimai Kanadoje yra gana aktualūs, nes, dar $2014 \mathrm{~m}$. duomenimis, net vienas iš trijų kanadiečių per gyvenimą buvo susidūręs su nervų sistemos ligomis ar simptomais. Nurodoma, kad 100000 Kanados gyventojų teko 980 smegenų infarktų (stroke) atvejų, 290 išsėtinès sklerozès atvejų, 360 nugaros smegenų pažeidimų, 410 galvos smegenų traumų ir 10 Hantingtono ligos atvejų. Tad kanadiečiai mokslininkai išanalizavo, kiek šokio intervencija gali paveikti judesių bei jutimo sutrikimus, kurie ir nulemia pablogėjusią eiseną, pusiausvyrą ir sumažejusi judumą. Jie atkreipé dėmesi, kad šokio intervencijos metu skambėdavo įvairi muzika. Pavyzdžiui, poūmio smegenų infarkto (sub-acute stroke) simptomams mažinti buvo pasitelkiami džiazo šokiai, merengue, galvos smegenų infarkto padarinių (chronic stroke) simptomams - tango ir baleto šokiai, įvairioms nugaros smegenų ligoms - rumba, tango ir salsa, išsėtinès sklerozès simptomams - salsa, o Hantingtono ligai - vaizdo žaidimų programa Dance Dance Revolution. Tiriamųų amžius įvairiuose tyrimuose svyravo nuo 43 iki $73 \mathrm{~m}$. Tyrimo rezultatai parodè, kad ankstyvame šio pobūdžio reabilitacinès veiklos etape šokio intervencijos panaudojimas, gydant nervų ligomis sirgusius suaugusius asmenis, pasiteisino. Šokiai teigiamai veikè neurodegeneracinėmis ligomis sergančių pacientų eiseną, pusiausvyrą ir gebejjimą judèti.

İdomų tyrimo aspektą pasirinko Lietuvos sveikatos mokslų universiteto ir Klaipedos universiteto mokslininkai Alvydas Soraka, Ligija Švedienė ir Laima Sapežinskienè. Aiškindamiesi pacientų su įvairiais nugaros smegenų pažeidimais gydymo ypatumus, jie pabandè nustatyti šokio poveiki didinant jų savarankiškumą ir pusiausvyrą (tyrimas paskelbtas 2009 m.). Paaiškejjo, kad eksperimentinès grupės tiriamujų, kuriems buvo taikoma šokio intervencija, savarankiškumas padidejo net $85 \%$, kai kontrolinès grupès dalyvių jis pagerejjo tik $48 \%$ [33]. Vèlesnių tyrimų metu (paskelbta 2013 m.) A. Soraka, L. Sapežinskienė ir Giedrius Sapežinskas nustate teigiamą sportinių šokių terapijos poveiki reabilituojant ir integruojant ic lokalią bendruomenę žmones, kurie po ịvairių nugaros smegenų pažeidimų judèjo vežimèliuose [34].

Atliekama nemažai tyrimų apie šokio vaidmeni gerinant pažintines, emocines ir motorines funkcijas bei gydant ịvairius kitus sutrikimus. Pavyzdžiui, tiriant Sidnèjaus globos namų (Australija) asmenis, buvo nustatyta, kad galima suburti ir sergančių demencija šokejjų grupę. Tačiau šiuo atveju, nors ir buvo pastebimas teigiamas šokio poveikis, globos namų gyventojai vis tik labiau mėgo muzikuoti, negu šokti [35].

Einšteino senstančių žmonių tyrimo centro ir Alberto Einšteino medicinos kolegijos Bronkse (Niujorkas, JAV) devynių mokslininkų grupė dar 2003 m. atliko vyresnių nei 75 metų gyventojų ( $\mathrm{n}=469)$, kurie neturejjo demencijos požymių, tyrimą. Per penkerius metus demencija pasireiške 124 asmenims: 61 nustatyta Alzheimerio liga, 30 prasidejo kraujagyslinès demencijos simptomai, 25 atsirado mišrios demencijos požymiai, dar 8 išryškèjo kito tipo demencija. Tačiau tiems, kurie laisvalaiki siejo su aktyvia pažintine ir fizine veikla (skaitè, grojo muzikos instrumentais, žaidè susijusius su judejjimu stalo žaidimus ar šoko), demencijos rizika buvo sumažejusi [36].

Išsamų klinikinį tyrimą atliko Seržipès federalinio universiteto (Brazilija) profesorè dr. Lavinia Teixeira-Machado. Ji nustatė, kad šokis gerina jaunų žmonių, sergančių cerebriniu paralyžiumi, kojų judesius. Šiame tyrime dalyvavo 26 tiriamieji, kurie buvo suskirstyti ị šokẻjų ir kontrolinę grupes. Tyrimas truko du mėnesius, užsièmimai vykdavo du kartus per savaitę po vieną valandą. Tyrimo rezultatai parodè, kad šokejjų grupejje pagerejjo kojų judesiai $(\mathrm{p}<0,05)$, o kontrolinès grupès dalyvių - pasyvūs judesiai $(\mathrm{p} \leq 0,05)$. Vadinasi, fizinė intervencija (šokis) gali padidinti cerebriniu paralyžiumi sergančių jaunų žmonių judesių amplitudę (angl. range of motion, ROM) [37].

Neurologines šokio terapijos galimybes praplečia ir įžvelgiamas šokio judesių poveikis lengvinant autizmo spektro sutrikimus. Brazilijos mokslininkų grupè, išnagrinëjusi 9350 įvairiose duomenų bazėse esančių studijų, pirmą kartą sistemiškai apžvelgė teigiamą šokio įtaką visam spektrui autizmo sutrikimų. Duomenų analizė parodè, kad šokių praktika autizmo sutrikimų turintiems asmenims stimuliuoja produktyvesnị bendravimą, gerina kūno dalių ir judesių suvokimą, didina emocinės saviraiškos, akių kontakto, empatijos galias [38].

Populiarumo sulaukia programos, kuriose šokis siejamas su kitomis poveikio pacientui priemonemis. Tokia yra Amsterdame ịkurta pirmoji, specialiai išsėtinei sklerozei skirta programa Switch2Move Multiple Sclerosis, kurioje sujungta šokio, meditacijos ir judesio terapija. Šios programos tikslas - pagerinti sergančių išsètine skleroze fizinę ir dvasinę būklę [39].

Prie retesnių degeneracinių susirgimų priskiriama Hantingtono liga. Nors ji nepagydoma, noredami palengvinti simptomus, Ohajo valstijos universiteto (JAV) neuromokslininkai pasitelkẻ nemedikamentinị ir neinvazini būdą - panaudojo Japonijoje 1998 m. sukurtą ir greitai išpopuliarẻjusị vaizdo muzikini žaidimą Dance Dance Revolution. Šis žaidimas, pagrịstas mišria ritmika ir įvairiais šokių žanrais, atliekamas ant scenos arba šokių aikštelèje. Ištyrus Dance Dance Revolution poveikị Hantingtono liga sergantiems pacientams, tyrimo pabaigoje (po 6 savaičių) buvo nustatytas ne tik pagerèjęs žaidimo atlikimas, didesnis pasitenkinimas žaidimu ir išaugęs susidomėjimas tęsti žaidimą, bet ir pagerẻjusi eisena, sklandesnis èjimas pirmyn ir atgal. Nors kiti rodikliai, pavyzdžiui, judesių koordinacija, pusiausvyra ir gyvenimo kokybė, beveik nepakito [40].

Kalbant apie ŠTN ir tikintis jos optimistinių perspektyvų, pravartu prisiminti vieną su šokiu susijusią ypatybę, kuri, deja, šiek tiek apriboja gydymo šokiu galimybes. Antai dar 2005 m. genetikos žurnalas paskelbè tyrimo rezulta- 
tus, įrodančius šokèjų, sportininkų ir nešokančiųų ar nesportuojančiųjų skirtingą genetinę prigimtį [41]. Pasirodo, kad šių grupių individai labai skiriasi tiek šokio gebẻjimais, tiek polinkiu ir poreikiu šokti. Skirtumą lemia kaip tik jų genetika (genetinis polimorfizmas). Grupė Izraelio mokslininkų, kartu su vienu tyrejju iš Prancūzijos, iškèlè hipotezę, kad du polimorfiniai genai - arginino vazopresino 1a receptorius $(A V P R l a)$ ir serotoninas transporteris (SLC6A4) - gali suaktyvinti meninị kūrybiškumą. Ištyrus pasirodymuose dalyvaujančių 85 šokẻjų ir jų šeimų genotipus, buvo nustatytas serotonino pernešejas (SLC6A4) ir arginino vazopresino receptorius 1a (AVPRla). Tokiu pat būdu dar buvo ištirtas 91 aktyvus, varžybose dalyvaujantis sportininkas ir grupè nešokančiųjų ar nesportuojančiųu (n = 872 asmenys iš 414 šeimų). Šokejjų AVPRla haplotipo dažniai (RS1 ir RS3) gerokai skyrèsi tiek nuo sportininkų $(p=0,000044)$, tiek nuo nešokančiųjų ar nesportuojančiųjų ( $\mathrm{p}=0,000024)$. Tyrejjai spejja, kad sąsajos tarp AVPRla ir SLC6A4 genų taip pat veikiau atspindi šokejų fenotipui būdingus socialinio bendravimo ir dvasiškumo aspektus negu šio kompleksiško fenotipo sensomotoriką. Tad ị genetikų atrastą dėsningumą, kad didesni ar mažesni šokio gebejjimai ir polinkis šokti būna nulemti genetiškai, neabejotinai reikètų atsižvelgti vykdant šokio intervenciją.

Šokio poveikis, mažinant PL simptomus, vis didesnių tango gydomujų galių atskleidimas, galiausiai šokio poveikis, lengvinant demencijos sutrikimus, mažinant kardiovaskulinių susirgimų riziką, minimalizuojant autizmo sutrikimų turintiems asmenims normalaus gyvenimo kliūtis ir gydant kitokius neurologinio pobūdžio sutrikimus, rodo išaugusias ŠTN galimybes. Maža to, šokio terapinių galių raiška vien šokiu jau neapsiriboja. Kitame skyriuje aprašoma, kaip tyrimai atskleidė papildomas neurologinių sutrikimų gydymo galimybes, leidusias pasiūlyti naują gydymo šokiu modelị.

\section{ŠOKIO POVEIKIO IR ESTETINIO PATYRIMO GYDOMASIS VAIDMUO}

Kuo skiriasi žiūrovo nervinès reakcijos, estetiškai vertinant šoki, nuo šokejjo smegenyse vykstančių nervinių reakcijų? Atsakymo ị šį klausimą ieškoti èmési grupe Bangoro universiteto (Jungtinė Karalystė, Šiaurès Velsas) mokslininkų. Tyrime dalyvavo 22 suaugę šokèjai, visi be šokimo patirties ir visi tik dešiniarankiai. Jie keturias dienas buvo mokomi atlikti šokių dalis ir jas stebėti. Kiekvieną kartą funkcinio magnetinio rezonanso tomografu (angl. functional magnetic rezonance imaging, fMRI) buvo fiksuojamos šokio ir atliktų šokio dalių stebejjimo nervinès reakcijos. Buvo žinoma, kad, stebint kitų žmonių veiksmus, įsijungia sensomotorinės smegenų dalys, kurios apibendrintai vadinamos veiksmų stebejjimo tinklu (angl. action observation network, AON). Atskiros nervinès dalys teigiamai veikia estetinius sprendimus, kuriuose dalyvauja AON sudarančios kūno somatosensorinès žievès dalys, požievinè atlygio sistema (angl. subcortical reward cir- cuitry) ir prefrontalinès žievès dalys. Visos jos dalyvauja estetinių sprendimų apdorojime ir vertinime. Analizuodami fMRI gautus vaizdus, tyrèjai pastebejjo svarbų dėsningumą, kad tyrimo dalyviai visada jausdavo didesnị pasitenkinimą, kai stebėdavo jau šoktas ar matytas dalis [42] Beje, ši Bangoro universiteto mokslininkų įžvalga, kad estetinis pasitenkinimas didẻja pakartotinai stebint šokius, yra panaši ị vis didesnị grožejjimąsi muzikos kūriniais, kai klausomasi jų pakartotinai. Ukrainiečių pedagogas Vladimiras Ostromenskis, prieš beveik penkis dešimtmečius atlikęs muzikos klausymosi ypatumų tyrimus, empiriškai nustatè, kad noras atnaujinti anksčiau patirtą estetinị pasitenkinimą yra esminis bendravimo ne tik su meno kūriniais, bet ir su grožiu apskritai bruožas [43]. Atsižvelgti ị ši estetinio suvokimo ypatumą pravartu tiek edukacinejje, tiek terapinejje veikloje.

Kitas šokio estetinio suvokimo ypatumas, kurị įžvelgė Bangoro universiteto tyrëjai, yra susijęs su skirtingomis nervinėmis reakcijomis, kurios vyksta šokant ir stebint šokị. Buvo nustatyta, kad šokio žiūrovų estetinès reakcijos iš požievio srities, kuri susijusi su dopaminergine atlygio sistema (angl. dopaminergic reward processing), pereina $i$ užpakalinę smilkininę sritị, kuri jau siejama su multisensorine integracija, emocijomis ir judejjimu [42]. Vadinasi, šokejjo ir šokio žiūrovo smegenyse iš tikrujų vyksta skirtingos nervinès reakcijos. Plètojant ŠTN strategiją, šiuos šokio estetinio suvokimo ypatumus galima būtų išnaudoti tikslingai, atsižvelgiant ị gydymo situaciją.

I šokio estetinio suvokimo ir šokẻjų judesių ryšio su smegenimis tyrimus sėkmingai ịsitraukè suomių šokèja ir neuromokslininkè dr. Hanna Poikonen. Daktaro disertacijoje, kurią 2018 m. apgynė Helsinkio universiteto Medicinos fakultete, ji išplètojo metodiką, skirtą geriau suprasti šokio sukuriamus procesus smegenų žievèje [44]. Šokio neuromokslą praturtino jos įžvalga, kuri atsiskleidè tyrimo metu. Paaiškejjo, kad judesiai, atliekami kartu grojant ar šokant, dviejų žmonių smegenų virpesius suderina ị tą patị dažnị. Akivaizdžiai išryškẻjo, kaip kartu šokančių tyrimo dalyvių žemo dažnio smegenų bangos ima sutapti arba, vartojant suomių mokslininkès terminą, „sinchronizuojasi“. Tokia smegenų bangų sinchronizacija šokẻjų sąveiką daro vientisą, kuri yra būtina siekiant harmoningai atlikti tiek šokio judesius, tiek muzikos kūrinị. O pačią galimybę prisiderinti prie kito asmens smegenų dažnio, kuri ypač išryškejja šokant, H. Poikonen vertina kaip esminę empatiškos visuomenès funkciją, stiprinančią humaniškumą.

Elektroencefalografijos (EEG) laboratorijoje suomių mokslininkai nuodugniau ištyrė dalyvių smegenų bangų sinchronizaciją. Profesionalių šokejjų ir muzikų smegenų funkcijas, jiems žiūrint šokių vaizdo ịrašus, jie palygino su smegenų funkcijomis kitų dalyvių, kurie neturèjo nei šokio, nei muzikinès patirties, bet taip pat peržiūrèjo tuos pačius vaizdo ịrašus. Tyrimas atskleidè, kad, staigiai pasikeitus muzikai ir audiovizualiniams pasirodymams, kisdavo ir grupių dalyvių smegenų aktyvumas. Ir čia išaiškejjo, kad šokejų smegenys reaguodavo ị pasikeitusią muziką greičiau negu profesionalių muzikų ar kontrolinès grupės narių. Kartu išryškèjo šokèjų geresnè žemo teta bangų dažnio 
(4-8 Hz) sinchronizacija, ją palyginus su kitų grupių nariais. Žinoma, kad kaip tik žemo dažnio bangų sinchronizacija yra susijusi su emocijomis bei atmintimi ir vaidina svarbų vaidmenị tarpasmeniniame bendravime [45]. Todèl, apibendrindami eksperimento rezultatus, tyrejjai rekomenduoja juos taikyti muzikos ir šokio terapijoje. Jie gali būti naudingi ir ugdymo procese, kai siekiama suprasti ir išnaudoti smegenų plastiškumo galimybes arba kai mokomasi atlikti motorikos, kognityvines ir su emocionalumu susijusias užduotis (tiek šokant, tiek grojant) [46].

Heidelbergo universiteto (Vokietija) Terapijos mokslų fakulteto devyni dèstytojai nusprendè ne tik išsiaiškinti šokio poveiki psichologinei savijautai bei kūno veiksmingumui, kas buvo praktikuojama iki tol, bet ir pagrịsti estetini šokio patyrimą, kaip svarbų gydomaji veiksnį. Su 34 Pietu Vokietijos PL sergančiais pacientais buvo vykdomi šokio užsièmimai, skambant argentinietiškam tango. Tango šokis juos labiausiai sudomino improvizacine prigimtimi, kuri labiau nei pramoginiai šokiai tiko eisenai ir pusiausvyrai gerinti. Be to, tango metrinè ritmika padeda pacientams įveikti sunkumą išjudèti, ypač akcentuota pirmoji takto dalis. Eksperimento duomenų analizè taip pat parodè, kad išaugo pacientų poreikis grožètis kūnu ir kūno judesiais bei žavètis kalbos laisvumu ir muzika. Jie pajuto ir bendrumo su partneriu grožį bei apskritai padaugejjo estetinio vertinimo aspektų. Galiausiai jie ėmė jausti pasitenkinimą holistiniu šokio patyrimu per se. Bet svarbiausia, kad estetinis pacientų patyrimas tiesiogiai koreliavo su gerèjančia savijauta. İ tai atsižvelgdami, Heidelbergo universiteto mokslininkai pasiūlè gydymo modelị, kuriame estetiškumas, ypač grožio patyrimas, priskiriamas prie pagrindinių meno intervencijos aspektų. Jie įsitikino, kad estetinio patyrimo didejimas neurologinejje šokio terapijoje yra svarbus sveikatos gerẻjimo rodiklis, kurị vaizdingai pavadino sveikatos pranašu [47]. Neabejotina, kad ši įžvalga ne tik papildo ŠTN galimybes, bet ir yra svarus indèlis ị visą menų neuroterapiją.

\section{ŠOKIO POREIKIO AUGIMAS SVEIKATINGUMO PROGRAMOSE}

Šokio judesiai, kaip ir specialūs neurologiniai judesių pratimai, turi galią žadinti smegenyse teigiamas emocijas, o jos, savo ruožtu, mažina migdolinio kūno (baimès ir streso centro smegenyse) aktyvumą. Kadangi tinkami šokio stiliai kelia šokèjų euforiją, leidžia užmiršti nuovargi, aktyvina fizini judéjimą, dẻl to šokio populiarumas auga. Šokio psichologini poveiki gerokai išplečia nežodinio bendravimo galimybẻs, leidžiančios šokantiesiems apsikeisti jiems suprantamomis emocinėmis žinutemis. Toks nežodinis bendravimas šokant ryškiai kontrastuoja su dabar daugeli pavergusiu virtualiu bendravimu tekstais ir vaizdais.

Lytẻjimo pojūtis dar ịdomus tuo, kad jis žmogui pirmiausia nustato ribą tarp jo kūno ir išorinio pasaulio. Prisilietimo reikšmę puikiai išmanantys gydytojai praktikai ge- rai žino, ką jų prisilietimas reiškia pacientui. Juk prisilietus iškart suaktyvejja atitinkamos smegenų dalys, o dẻl kraujo pritekẻjimo ị jas, padidẻja neuronų aktyvumas. Prisilietimai yra ypač svarbus porinių šokių elementas, nes leidžia pajausti partnerio kūno kalbą. Atliekant fMRI, matyti ịvairialypis prisilietimų poveikis smegenims, pasireiškiantis tiek sąmonès, tiek pasąmonès lygiu.

Bendravimą šokant sustiprina ir tam tikras prisilietimų žodynas. Linšiopingo universiteto (Švedija) neurologu grupė nustatė, kad emociškai artimi žmonès geba atpažinti kai kurių žodžių (pvz., dẻkingumo, liūdesio) reikšmes tik pagal lytėjimo pojūtị. Paaiškèjo, kad, netgi esant minimaliam kontekstui ir negaunant grị̌ztamojo ryšio, bendravimas gali vykti stebètinai sẻkmingai [48].

Šokių mokymo praktikoje prisilietimai veikia pojūčius, judesius, tam tikrą minčių eigą, netgi pagerina gebẻjimą išmokti naujus judesius. Tikètina, kad prisilietimo atvejais odos ir raumenu receptoriai per nugaros smegenis perduoda signalą kaip tik ị somatosensorinès žievès sritị. Lytejimas taip pat veikia smegenu pamato branduolius, kurie aktyvuojasi, pavyzdžiui, mokantis naujų judesių. Atliekant fMRI buvo nustatyta, kad partnerio lietimas yra susijęs su daugelio smegenų dalių aktyvacija, ịskaitant somatosensorinę žievę, salą, viršutinị smilkininị vingị, antkraštinị vingị (supramarginal gyrus), dryžuotajị kūną, migdolinį kūną, smegenèles ir prefrontalinę žievę [49]. Terapiniu požiūriu yra svarbu, kad ši aktyvacija teigiamai pasireiškia sutrikus judesiams, tarkim, sergant PL. Taigi, šokant poromis, kito asmens lytėjimas, darantis poveiki ịvairioms smegenų dalims, gali teigiamai veikti pacientų būklę.

Svarbu pažymėti, kad lytėjimo poveikio spektras yra gana platus. Antai liečiant galima sumažinti skausmą, baimę, stresą, nerimą ir kitus sutrikimus. Šokejja ir neuromokslininkè H. Poikonen parengė komunikavimo su plačia auditorija metodą, kuri pavadino WiseMotion. Taikant ši metodą, atliekant įvairius judesius, meditaciją ir atsižvelgiant ị neuromokslinių tyrimų rezultatus, užsièmimuose lavinami skirtingų grupių dalyvių fiziniai gebèjimai, tobulinamas kūno judesių suvokimas ir gerinama smegenų būklè. Ši suomių neuromokslininkès veikla tiesiogiai nesisieja su neuroterapija, tačiau atlieka nepaprastai svarbų vaidmenị prevencinèje medicinoje. Šiandien ypač aktualu tai, kad, stiprinant smegenų būklę ir fizinius gebejjimus, gerèja adaptavimosi prie didesnių pokyčių galios. Jų svarba itin išryškejja pandemijos sąlygomis. Pagaliau neurologų, taip pat ir šokio neuroterapeutų, profesinę tapatybę sėkmingai praplečia ir sutvirtina įsigalinti nauja gydymo paradigma, kai vis daugiau dėmesio skiriama sveikų žmonių sveikatos gerinimui [50].

Aptariamame kontekste gerai atrodo Kinestezijos akademijos Kaune surengtas teorinis-praktinis seminaras „Šokio ir judesio terapija, taikant argentinietiško tango elementus: kinestetinis ir haptinis prisilietimas“, skirtas tiek turintiems, tiek neturintiems sveikatos sutrikimų. Lankytojai šalia individualių, porinių ir grupinių šokių ịgūďių, taip pat mokomi taikyti kinestetinio ir haptinio prisilietimo intervencijas [51]. 
Nors šokio terapijos tyrimai ir praktiniai užsiėmimai populiarėja, ŠTN aprèptį šiek tiek mažina tam tikri ribojimai. Antai žmonès, turintys sunkiai įveikiamas fizines negalias, ir tie, kurių haplotipas, kaip parodė anksčiau aprašytas genetinis tyrimas, nėra palankus skleistis šokio gebėjimams ir neturi polinkio šokti, i ŠTN sferą sunkiai patenka. Vis dẻlto, žvelgiant ị pateiktus mokslinių tyrimų pavyzdžius, akivaizdu, kad, gebant šokti ir turint trauką šokiui, jis tampa svaria neuroestetikos šaka. $\mathrm{O}$ dèl daugelio jau įrodytų gydomųjų galių, šokis tampa vis svarbesniu instrumentu tiek gydant nervų ligas ir lengvinant sutrikimus, tiek atliekant reabilitaciją ir mažinant nervų ligų susirgimo riziką.

\section{IŠVADOS}

Neuromokslams išaiškinant šokio ryšį su smegenimis, didejja jo vaidmuo gydant nervų ligomis sergančius ligonius. Šokio terapijos plètojimo tendenciją dar labiau sustiprina atsirandantys nauji gydymo, reabilitacijos ir prevencijos metodai. Visa tai rodo, kad nervų ligu gydymo sistemoje susiformavęs reiškinys igauna autonominio konstrukto bruožus ir gali būti apibendrintas šokio terapijos neurologijoje (ŠTN) terminu.

Gydymui, reabilitacijai ir (ar) profilaktikai taikomi įvairūs šokiai: tango, salsa, sambo, rumba, lindihopas, merengue, baletas ir kiti, tačiau nepralenkiamas pagal tyrimu dažnumą - tango. Šokių, pasitelkiamų gydymo intervencijai, gausa rodo išaugusias ŠTN galimybes.

Apžvelgiant publikacijas, paaiškèjo, kad ŠTN kontekste dažniausiai atliekami PL gydymo šokiu tyrimai. Kartu daugèja daugelio nervų ligų ir sutrikimų (cerebrinio paralyžiaus, Alzheimerio ligos, neuroraumeninių ligų, autizmo, protinio atsilikimo, depresijos ir pan.) simptomų lengvinimo šokiais tyrimų. Tyrimų rezultatai parodė, kad šokis daro teigiamą poveikị tiriamujų eisenai, pusiausvyrai, gerina kognityvines funkcijas (kaktinės skilties veiklą), palengvina apatijos ir depresijos simptomus, teigiamai veikia protinius ir bendruosius ligos sutrikimus.

Atsirado darbų, įrodančių šokio estetinio suvokimo daromą teigiamą poveiki smegenims. Neuromoksliniai tyrimai atskleidè, kad šokejjų žemo dažnio (4-8 Hz) teta bangos geriau sinchronizuojasi (sutampa) negu kitu grupių narių. Tai ypač teigiamai veikia tarpasmenini bendravimą ir abipusi supratimą, nes siejasi su emocijomis ir atmintimi. Be to, šokant poromis, kito asmens lytejimas, aktyvinantis ịvairias smegenų dalis, teigiamai veikia pacientų būklę.

Šokio metu lavinami fiziniai gebejjimai, tobulinamas kūno judesių suvokimas ir gerinama smegenų būklè atlieka nepaprastai svarbų vaidmenị prevencinèje medicinoje. Pati galimybė prisiderinti prie kito asmens vertinama kaip esminè empatiškos visuomenès funkcija, stiprinanti humaniškumą. Gerẻjančios galimybès prisiderinti prie didesnių pokyčių itin išryškėja pandeminėmis sąlygomis.

Plètojantis neurologinių sutrikimų lengvinimo šokiu tyrimams, taip pat pasirodant naujiems gydymo mode- liams ir augant praktinės neuroterapinès veiklos poreikiui, būtų gerai, jeigu Lietuvos šokio-judesio terapijos asociacijos mokslinių tyrimų ir taikomoji veikla, taip pat Vilniaus universiteto Medicinos fakulteto judesio ir šokio terapijos magistrantūros programa būtų praplèstos progresuojančia ŠTN specializacija.

\section{Literatūra}

1. Širvinskienė A. Pagrindinių klasių mokinių ritmiškumo lavinimas solfedžio pamokose taikant šiuolaikinès muzikos ritmus. Magistro darbas. Vilnius: Vilniaus pedagoginis universitetas, 2008 [žiūrèta 2020-09-09]. Prieiga per internetą: https://view.officeapps.live.com/op/view.aspx?src=http\%3 A\%2F\%2Ftalpykla.elaba.lt\%2Felaba-fedora\%2Fobjects \% 2 Felaba\%3A1803770\%2Fdatastreams\%2FATTACHMENT 1803774\%2Fcontent

2. List of neurological disorders and their descriptions. Disabled World. 2016 [cited 2020 August 9]. Available from: https://www.disabled-world.com/health/neurology/ disorders-list.php

3. List of dances. 2020 [cited 2020 July 10]. Available from: https://en.wikipedia.org/wiki/List_of_dances

4. Bruyneel A-V. Effects of dance activities on patients with chronic pathologies: scoping review. Heliyon 2019; 5(7): e02104. https://doi.org/10.1016/j.heliyon. 2019.e02104

5. Menų terapija (šokio-judesio terapija) [žiūrèta 2020-09-19]. Prieiga per internetą: https://www.vu.lt/studijos/ stojantiesiems/magistro-studiju-sarasas/menu-terapijasokio-judesio-terapija\#profesines-veiklos-galimybes

6. Kaski D, Bronstein AM. Treatments for neurological gait and balance disturbance: the use of noninvasive electrical brain stimulation. Advances in Neuroscience 2014; Article ID 573862. https://doi.org/10.1155/2014/573862

7. Kusmiati S, Nurgiwiati E, Hamzah A. Salsa dance could improve effectively to body balance in elderly with risk of falls. Open J Nurs 2018; 8(11): 771-8. https://doi.org/10.4236/ ojn. 2018.811058

8. Lazarou I, Parastatidis T, Tsolaki A, et al. International ballroom dancing against neurodegeneration: a randomized controlled trial in Greek community-dwelling elders with mild cognitive impairment. Am J Alzheimers Dis Other Demen 2017; 32(8): 489-99. https://doi.org/10.1177/ 1533317517725813

9. Kropacova S, Mitterova K, Klobusiakova P, et al. Cognitive effects of dance-movement intervention in a mixed group of seniors are not dependent on hippocampal atrophy. J Neural Transm (Vienna) 2019; 126(11): 1455-63. https://doi.org/ 10.1007/s00702-019-02068-y

10. Lossing A, Moore M, Zuhl M. Dance as a treatment for neurological disorders. Body Mov Dance Psychother 2017; 12(3): 170-84. https://doi.org/10.1080/17432979. 2016.1260055

11. Armstrong MJ, Okun MS. Diagnosis and treatment of Parkinson disease: a review. JAMA 2020; 323(6): 548-60. https://doi.org/10.1001/jama.2019.22360

12. Tillmann AC, Andrade A, Swarowsky A, Guimarães ACA. Brazilian samba protocol for individuals with Parkinson's disease: a clinical non-randomized study. JMIR Res Protoc 2017; 6(7): e129. https://doi.org/10.2196/resprot.6489

13. Argentinietiškas tango žmonėms su Parkinsonu ir jų partneriams. Vilniaus mokytojų namai. Kultūros ir švietimo 
centras [žiūrèta 2020-09-11]. Prieiga per internetą: http://www.kultura.lt/lt/articles/view/527

14. Sergantiems Parkinsono liga - nauja galimybè Vilniuje. Lrytas.tv [žiūrèta 2020-09-11]. Prieiga per internetą: https://tv.lrytas.lt/zinios/lietuvos-diena/2017/11/18/news/ sergantiems-parkinsono-liga-nauja-galimybe-vilniuje3560343/

15. Hashimoto H, Takabatake S, Miyaguchi H, et al. Effects of dance on motor functions, cognitive functions, and mental symptoms of Parkinson's disease: a quasi-randomized pilot trial. Complement Ther Med 2015; 23(2): 210-9. https://doi.org/10.1016/j.ctim.2015.01.010

16. McGill A, Houston S, Lee RYW. Effects of a ballet-based dance intervention on gait variability and balance confidence of people with Parkinson's. Arts Health 2018; 11(2): 133-46. https://doi.org/10.1080/17533015. 2018.1443947

17. McGill A, Houston S, Lee RYW. Effects of a ballet intervention on trunk coordination and range of motion during gait in people with Parkinson's. Cogent Medicine 2019; 6(1): 1583085. https://doi.org/10.1080/2331205X. 2019.1583085

18. Michels K, Dubaz O, Hornthal E, Bega D. "Dance therapy" as a psychotherapeutic movement intervention in Parkinson's disease. Complement Ther Med 2018; 40: 248-52. https://doi.org/10.1016/j.ctim.2018.07.005

19. Hulbert S, Ashburn A, Roberts L, Verheyden G. Dance for Parkinson's - the effects on whole body co-ordination during turning around. Complement Ther Med 2017; 32: 91-7. https://doi.org/10.1016/j.ctim.2017.03.012

20. Rocha PA, Slade SC, McClelland J, Morris ME. Dance is more than therapy: qualitative analysis on therapeutic dancing classes for Parkinson's. Complement Ther Med 2017; 34: 1-9. https://doi.org/10.1016/j.ctim.2017.07.006

21. Shanahan J, Ní Bhriain O, Morris ME, et al. Irish set dancing classes for people with Parkinson's disease: the needs of participants and dance teachers. Complement Ther Med 2016; 27: 12-7. https://doi.org/10.1016/j.ctim.2016.04.001

22. Lötzke D, Ostermann T, Büssing A. Argentine tango in Parkinson disease - a systematic review and meta-analysis. BMC Neurology 2015; 15: 226. https://doi.org/10.1186/ s12883-015-0484-0

23. Koh Y, Noh G. Tango therapy for Parkinson's disease: effects of rush elemental tango therapy. Clin Case Rep 2020; 8(6): 970-7. https://doi.org/10.1002/ccr3.2771

24. Koh Y, Hur Y, Noh G. Basic tango elements for tango therapy. Journal of Tango 2019; 1(1): 1-5.

25. Koh Y, Hur Y, Noh G. Terminology of Argentine tango for tango therapy. Journal of Tango 2019; 1(1): 7-17.

26. Koh Y, Hur Y, Noh G. Tango posture and stance: functional anatomical analysis and therapeutic characteristics. Journal of Tango 2019; 1(1): 19-32.

27. Koh Y, Kim ICS, Noh G. Tango therapy: current status and the next perspective. J Clin Rev Case Rep 2018; 3(8): 1-5. https://doi.org/10.33140/JCRC/03/08/00005

28. Hackney ME, Earhart GM. Effects of dance on gait and balance in Parkinson's disease: a comparison of partnered and nonpartnered dance movement. Neurorehabil Neural Repair 2010; 24(4): 384-92. https://doi.org/10.1177/ 1545968309353329

29. Romenets SR, Anang J, Fereshtehnejad SM, et al. Tango for treatment of motor and non-motor manifestations in Parkinson's disease: a randomized control study. Complement Ther
Med 2015; 23: 175-83. https://doi.org/10.1016/j.ctim. 2015.01.015

30. Albani G, Veneziano G, Lunardon C, et al. Feasibility of home exercises to enhance the benefits of tango dancing in people with Parkinson's disease. Complement Ther Med 2019; 42: 233-9. https://doi.org/10.1016/j.ctim.2018.10.028

31. Beerenbrock Y, Meyer L, Böhme J, et al. Perceived effects of tango argentino on body experience in persons with Parkinson's disease (PD) - a qualitative study with affected persons and their partners. Complement Ther Med 2020; 48: 102221. https://doi.org/10.1016/j.ctim.2019.102221

32. Patterson KK, Wong JS, Prout EC, Brooks D. Dance for the rehabilitation of balance and gait in adults with neurological conditions other than Parkinson's disease: a systematic review. Heliyon 2018; 4(3): e00584. https://doi.org/10.1016/ j.heliyon.2018.e00584

33. Sapezinskiene L, Soraka A, Svediene L. Dance movement impact on independence and balance of people with spinal cord injuries during rehabilitation. Int J Rehabil Res 2009; 32: S100. https://doi.org/10.1097/00004356200908001-00130

34. Soroka A, Sapežinskienè L, Sapežinskas G. Žmonių po nugaros smegenų pažeidimo, judančių vežimèliuose, reabilitacija lokalioje bendruomeneje, taikant sportinių šokių terapiją. Reabilitacijos metodų ir priemonių efektyvumas. Lietuvos reabilitologų asociacijos konferencijos medžiaga. Kaunas: Naujasis lankas, 2013; 240-2.

35. Low LF, Carroll S, Merom D, et al. We think you can dance! A pilot randomised controlled trial of dance for nursing home residents with moderate to severe dementia. Complement Ther Med 2016; 29: 42-4. https://doi.org/10.1016/ j.ctim.2016.09.005

36. Verghese J, Lipton RB, Katz MJ, et al. Leisure activities and the risk of dementia in the elderly. N Engl J Med 2003; 348(25): 2508-16. https://doi.org/10.1056/NEJMoa022252

37. Teixeira-Machado L. Effect of dance on lower-limb range of motion in young people with cerebral palsy: a blinded randomized controlled clinical trial. Adolesc Health Med Ther 2019; 10: 21-8. https://doi.org/10.2147/AHMT.S177867

38. DeJesus BM, Oliveira RC, de Carvalho FO, et al. Dance promotes positive benefits for negative symptoms in autism spectrum disorder (ASD): a systematic review. Complement Ther Med 2020; 49: 102299. https://doi.org/10.1016/ j.ctim.2020.102299

39. Switch2Move Multiple Sclerosis. [cited 2020 August 14]. Available from: https://switch2move.com/multiplesclerosis/

40. Kloos AD, Fritz NE, Kostyk SK, et al. Video game play (Dance Dance Revolution) as a potential exercise therapy in Huntington's disease: a controlled clinical trial. Clin Rehabil 2013; 27(11): 972-82. https://doi.org/10.1177/ 0269215513487235

41. Bachner-Melman R, Dina C, Zohar AH, et al. AVPRla and SLC6A4 gene polymorphisms are associated with creative dance performance. PLoS Genetics 2005; 15(4): e42. https://doi.org/10.1371/journal.pgen.0010042

42. Kirsch LP, Dawson K, Cross ES. Dance experience sculpts aesthetic perception and related brain circuits. Ann N Y Acad Sci 2015; 1337: 130-9. https://doi.org/10.1111/nyas. 12634

43. Остроменский ВД. Восприятие музыки как педагогическая проблема. Киев: Музична Украіна, 1975.

44. Poikonen H. A dancer's brain develops in a unique way. University of Helsinki. News, 2017 [cited 2020 August 23]. 
Available from: https://www.helsinki.fi/en/news/health/ a-dancers-brain-develops-in-a-unique-way

45. Poikonen H, Toiviainen P, Tervaniemi M. Dance on cortex: enhanced theta synchrony in experts when watching a dance piece. Eur J Neurosci 2018; 47(5): 433-45. https://doi.org/ 10.1111/ejn. 13838

46. Poikonen H, Toiviainen P, Tervaniemi M. Naturalistic music and dance: cortical phase synchrony in musicians and dancers. PLoS One 2018; 13(4): e0196065. https://doi.org/ 10.1371/journal.pone.0196065

47. Koch SC, Mergheim K, Raeke J, et al. The embodied self in Parkinson's disease: feasibility of a single tango intervention for assessing changes in psychological health outcomes and aesthetic experience. Front Hum Neurosci 2016; 10: 287. https://doi.org/10.3389/fnins.2016.00287

48. Mcintyre S, Moungou A, Böhme R, et el. Affective touch communication in close adult relationships. IEEE World Haptics Conference (WHC). Tokyo, 2019; 175-80. https://doi.org/10.1109/WHC.2019.8816093

49. Böhme R, Hauser S, Gerling GJ, et al. Distinction of self-produced touch and social touch at cortical and spinal cord levels. Proc Natl Acad Sci U S A 2019; 116(6): 2290-9. https://doi.org/10.1073/pnas.1816278116

50. Šeduikienė M, Matonis V. Neurologo profesinès tapatybės kismas. Neurologijos seminarai 2020; 24(83): 5-17. https://doi.org/10.29014/ns.2020.01

51. Šokio ir judesio terapija, taikant argentinietiško tango elementus: kinestetinis ir haptinis prisilietimas (2019.11.09). Teorinis-praktinis seminaras. Kinestezijos akademija [žiūrèta 2020-09-16]. Prieiga per internetą: https://ktakademija.lt/ courses/sokio-ir-judesio-terapija-taikant-argentinietiskotango-elementus-kinestetinis-ir-haptinis-prisilietimas2019-11-09/

\section{M. Šeduikienė, V. Matonis}

\section{DANCE THERAPY IN NEUROLOGY}

\section{Summary}

A review of recent dance therapy publications shows that most of the research is devoted to the treatment of neurological disorders or the relief of symptoms through dance. Tango, salsa, rumba, marengue, ballet, and other dance forms are employed in the treatment of Parkinson's disease, stroke, spinal cord injury, traumatic brain injury, etc. The increase in treatment cases shows the growing need for the healthcare system to use the possibilities of dance neurotherapy more effectively. The reviewed literature is divided into six sections: 1) increasing research into the therapeutic role of dance and growing popularity of dance therapy, 2) dance as an important neurotherapeutic means of motor, cognitive, emotional, spatio-visual, and social activation, 3 ) the role of dance in symptom alleviation in Parkinson's disease, 4) limitations and possibilities of enlargement of neurologic dance therapy, 5) the impact of aesthetic experience of dance on the nervous system, and 6) the growth of the need for dance in healthcare programs. Surprisingly, this important area of investigation and treatment through dance has yet to be named. Taking into account both the scope and specifics of dance therapy activities, it would be appropriate to refer to specialized dance therapy for the treatment of neurological disorders as dance therapy in neurol$o g y$ (DTN). Many of the beneficial effects of dance have great potential to alleviate the symptoms of nervous system disorders and correspondingly expand the possibilities of DTN

Keywords: dance therapy, neuroaesthetics, neurological disorders, Parkinson's disease, dance intervention.

Gauta:

Priimta spaudai:

20201012

2020123 